\title{
Microbial nitrogen cycling on the Greenland Ice Sheet
}

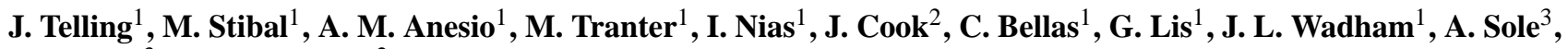 \\ P. Nienow ${ }^{3}$, and A. Hodson ${ }^{2}$ \\ ${ }^{1}$ Bristol Glaciology Centre, School of Geographical Sciences, University of Bristol, Bristol, BS8 1SS, UK \\ ${ }^{2}$ Department of Geography, University of Sheffield, Sheffield, S10 2TN, UK \\ ${ }^{3}$ School of GeoSciences, University of Edinburgh, Edinburgh, EH8 9XP, UK \\ Correspondence to: J. Telling (jon.telling@ bristol.ac.uk)
}

Received: 11 October 2011 - Published in Biogeosciences Discuss.: 25 October 2011

Revised: 7 April 2012 - Accepted: 22 May 2012 - Published: 5 July 2012

\begin{abstract}
Nitrogen inputs and microbial nitrogen cycling were investigated along a $79 \mathrm{~km}$ transect into the Greenland Ice Sheet (GrIS) during the main ablation season in summer 2010. The depletion of dissolved nitrate and production of ammonium (relative to icemelt) in cryoconite holes on Leverett Glacier, within $7.5 \mathrm{~km}$ of the ice sheet margin, suggested microbial uptake and ammonification respectively. Positive in situ acetylene assays indicated nitrogen fixation both in a debris-rich $100 \mathrm{~m}$ marginal zone and up to $5.7 \mathrm{~km}$ upslope on Leverett Glacier (with rates up to $16.3 \mu$ moles $\mathrm{C}_{2} \mathrm{H}_{4} \mathrm{~m}^{-2}$ day $^{-1}$ ). No positive acetylene assays were detected $>5.7 \mathrm{~km}$ into the ablation zone of the ice sheet. Potential nitrogen fixation only occurred when concentrations of dissolved and sediment-bound inorganic nitrogen were undetectable. Estimates of nitrogen fluxes onto the transect suggest that nitrogen fixation is likely of minor importance to the overall nitrogen budget of Leverett Glacier and of negligible importance to the nitrogen budget on the main ice sheet itself. Nitrogen fixation is however potentially important as a source of nitrogen to microbial communities in the debrisrich marginal zone close to the terminus of the glacier, where nitrogen fixation may aid the colonization of subglacial and moraine-derived debris.
\end{abstract}

\section{Introduction}

Glaciers and ice sheets cover $29.1 \%$ of the landmass within the Arctic, of which the Greenland Ice Sheet (GrIS) comprises $81 \%$ (Walker et al., 2005). Due to its large area, supraglacial ecosystems on the GrIS may be important to regional carbon cycling via the autochthonous production and downstream transport of carbon and nutrients (Anesio et al., 2009; Stibal et al., 2012). To date, however, only two studies have quantified microbial carbon cycling on the GrIS (Hodson et al., 2010b; Stibal et al., 2012), while no studies have examined microbial nutrient cycling on the GrIS.

Microbial nitrogen cycling will likely be vital in supporting the activity and growth of microorganisms on the GrIS; after carbon, the greatest nutrient on a cellular mass basis is nitrogen (Redfield et al., 1963). Microbial nitrogen cycling has been previously measured or indirectly inferred on glaciers. Nitrogen fixation can be active in cryoconite (surface sediment) holes on smaller Arctic valley glaciers, suggesting that nitrogen inputs from snowmelt, icemelt and organic remineralization can be insufficient to meet the demands of microbial growth (Telling et al., 2011). Microorganisms capable of nitrogen fixation have also been documented in sediment on a New Zealand glacier (Foght et al., 2004). Mass balance considerations suggest that nitrification may be important in glacial catchments in the Arctic (Hodson et al., 2005; Wynn et al., 2007), the Alps (Tockner et al., 2002), the Rockies (Baron et al., 1995; Campbell et al., 2000), and the maritime Antarctic (Hodson, 2006; Hodson et al., 2009). Significant ammonia retention has been demonstrated on the catchment scale of two Arctic valley glaciers, which may be due to microbial uptake (Hodson et al., 2008, 2010c). Microcosm experiments have indicated active nitrification and nitrate reduction, but not nitrogen fixation, beneath a Canadian glacier (Boyd et al., 2011).

Understanding nitrogen inputs and microbial nitrogen cycling on the GrIS can help determine the impact of anthropogenic pollution on supraglacial ecosystems. There have been significant increases in nitrogen deposition from 


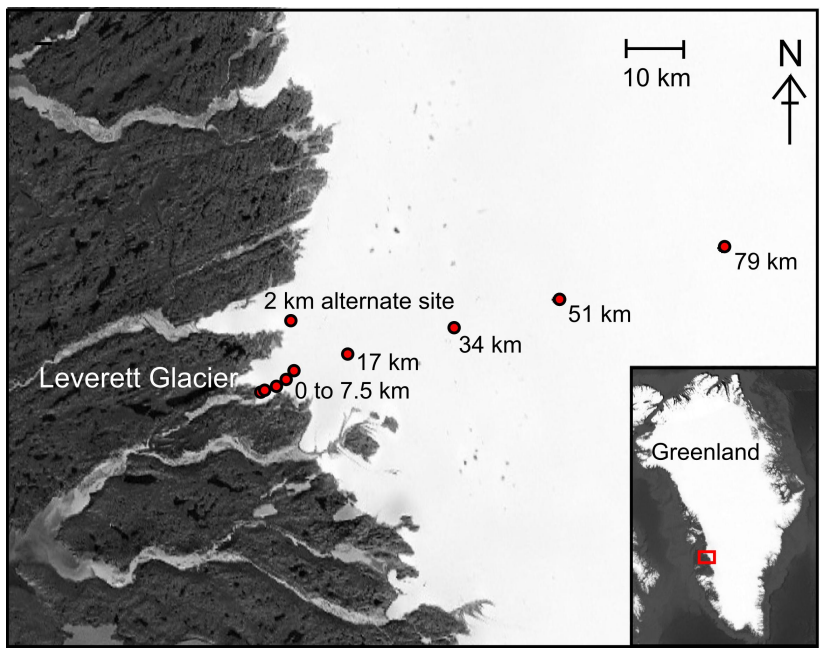

Fig. 1. Map showing location of transect sampling points ( 0 to $79 \mathrm{~km}$ ) and alternate $2 \mathrm{~km}$ site. Inset map shows location of sampling area within Greenland. The transect started at the terminus of Leverett Glacier ( $0 \mathrm{~km}$ site; $\left.67^{\circ} 04.17 .1^{\prime \prime} \mathrm{N}, 50^{\circ} 08.4 .2^{\prime \prime} \mathrm{W}\right)$ and ended $79 \mathrm{~km}$ into the ice sheet $\left(67^{\circ} 0910.8^{\prime \prime} \mathrm{N}, 48^{\circ} 22^{\prime} 14.6^{\prime \prime} \mathrm{W}\right)$. Satellite image base map from http://www.esri.com/software/ arcgis/arcgisonline.

anthropogenic sources on Arctic glaciers and the GrIS since preindustrial times (Kekonen et al., 2005; Olivier et al., 2006), and its impact on the nutrient-poor supraglacial environment has yet to be well established (Hodson et al., 2009).

In this study we test the hypothesis that there is active microbial nitrogen cycling on the GrIS by measuring microbial nitrogen fixation, relative nifH gene abundance and nitrogen chemistry over a $79 \mathrm{~km}$ transect into the GrIS, so covering the entire ablation zone. We estimate the importance of nitrogen fixation to the total input of nitrogen to the GrIS and to supporting net microbial growth on the ice sheet surface.

\section{Methods}

\subsection{Study locations, sampling and in situ physical measurements}

Nutrient analysis and nitrogen fixation assays were made along a $79 \mathrm{~km}$ transect on the GrIS $\left(67^{\circ} 04^{\prime} 17.1^{\prime \prime} \mathrm{N}\right.$, $50^{\circ} 08^{\prime} 45.2^{\prime \prime} \mathrm{W}$ to $67^{\circ} 09^{\prime} 10.8^{\prime \prime} \mathrm{N}, 48^{\circ} 22^{\prime} 14.6^{\prime \prime} \mathrm{W}$ ) (Fig. 1). Transect sites have previously been described in Stibal et al. (2010). The transect started from the terminus of Leverett Glacier on the western coast of Greenland, approximately $15 \mathrm{~km}$ inland from Kangerlussuaq (Fig. 1). Transect sites at $7.5 \mathrm{~km}, 17 \mathrm{~km}, 34 \mathrm{~km}, 51 \mathrm{~km}$ and $79 \mathrm{~km}$ were accessed by helicopter on 1 August and 2 August 2010. Transect sites at $0 \mathrm{~km}, 2 \mathrm{~km}, 4 \mathrm{~km}, 5.7 \mathrm{~km}$ and $7.5 \mathrm{~km}$ (repeated) were accessed by walking from the terminus of Leverett Glacier on 5 August and 6 August 2010 (Fig. 1). Cryoconite at the $0 \mathrm{~km}$ station was present as a relatively uniform apron of surface

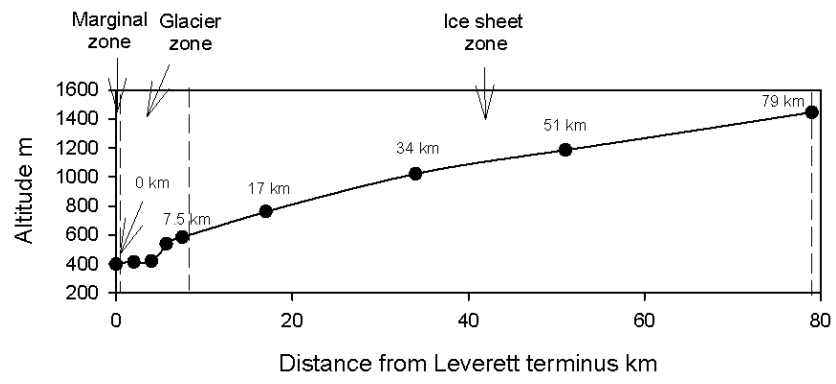

Fig. 2. Cross section through line of transect shown in Fig. 1. The transect is divided into three zones: (1) Marginal zone (0 to $0.1 \mathrm{~km})$, (2) Glacier zone $(0.1$ to $7.5 \mathrm{~km})$ and (3) Ice sheet zone (7.5 to $79 \mathrm{~km})$.

debris several $\mathrm{mm}$ thick overlying the ice in a zone extending approximately $100 \mathrm{~m}$ upslope from the glacier terminus. We define this as the marginal zone (Fig. 2). The $2 \mathrm{~km}$ through to $7.5 \mathrm{~km}$ sites are located on the main bulk of Leverett Glacier; we define this as the glacier zone (Fig. 2). Sites $>7.5 \mathrm{~km}$ are located on the ice sheet, and are defined as the ice sheet zone (Fig. 2).

No surface water was present at the marginal site; hence, only surface sediment (cryoconite) was sampled. At the glacier and ice sheet sites (with the exception of the $79 \mathrm{~km}$ site), both cryoconite and the overlying supraglacial waters were sampled. At the time of sampling, these cryoconite holes were open (i.e. holes without ice lids allowing gaseous exchange with the atmosphere) containing cryoconite one to several $\mathrm{mm}$ thick. The $79 \mathrm{~km}$ site was completely covered in slush, and cryoconite was present only as tiny sub $\mathrm{mm}$ grains dispersed within the slush. There was insufficient cryoconite collected at this site to allow solid phase nutrient analysis. There was no precipitation over the measurement period other than light snow at the $79 \mathrm{~km}$ site. Water samples for nutrient analysis were taken using a $50 \mathrm{ml}$ syringe and filtered through online $0.45 \mu \mathrm{m}$ Whatman ${ }^{\mathrm{TM}}$ cellulose nitrate filters into Nalgene ${ }^{\mathrm{TM}}$ HDPE bottles. All bottles were rinsed three times with filtered sample before collection. Cryoconite for nutrient analysis was sampled using a pipette and stored in sterile $15 \mathrm{ml}$ polypropylene centrifuge tubes. Samples were frozen at $-20^{\circ} \mathrm{C}$ and transported frozen back to Bristol for later chemical analysis.

At all sites, in situ bottle incubations were used to estimate rates of net ecosystem production (NEP; previously published in Stibal et al., 2012) and nitrogenase activity (via the acetylene assay) (see Sect. 2.3). Additional measurements of NEP and nitrogenase activity were made earlier in the season (6 June to 15 June 2010) at an alternate $2 \mathrm{~km}$ site located at the margins of the ice sheet (Fig. 1).

Continuous daily measurements (with occasional loss of data due to sensor failures) of total ablation along the transect were measured using Campbell SR50A ultra-sonic depth gauges at fixed ablation poles at the $2 \mathrm{~km}, 17 \mathrm{~km}, 51 \mathrm{~km}$ and 
$79 \mathrm{~km}$ sites over the course of the 2009 and 2010 melt seasons. Fresh snow was sampled using a snow shovel at the $0 \mathrm{~km}$ site in early June 2011, prior to the start of the melt season. Ice samples were taken along the transect at $0.4 \mathrm{~km}$, $0.6 \mathrm{~km}, 7 \mathrm{~km}, 8 \mathrm{~km}, 15 \mathrm{~km}, 35 \mathrm{~km}$, and $70 \mathrm{~km}$ sites in early June 2010 , and at $0 \mathrm{~km}$ and $2 \mathrm{~km}$ in early June 2011. Ice was sampled either as ice chippings using an ice axe or as short ( $\leq 70 \mathrm{~cm}$ deep) cores using a Kovacs ice corer (Fig. 1). All ice and snow samples were placed in pre-cleaned (rinsed $6 \times$ with MQ) polypropylene bags and transported frozen back to Bristol. Samples were melted in pre-cleaned (washed $6 \times$ with MQ) polypropylene bottles and then filtered through $0.45 \mu \mathrm{m}$ cellulose nitrate filters. Quadruplicate blank samples of MQ water in polypropylene bags were treated in an identical way to the samples to act as procedural blanks.

\subsection{Nutrient and total nitrogen analyses}

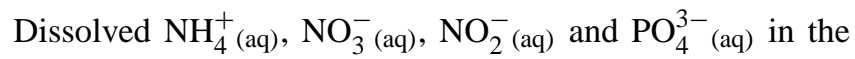
water, snow and ice samples were analyzed on a Bran and Luebbe AutoAnalyzer 3. The $\sum\left(\mathrm{NH}_{4}^{+}(\mathrm{aq})+\mathrm{NO}_{3}^{-}\right.$(aq) + $\mathrm{NO}_{2}^{-}$(aq) $)$is termed DIN. Detection limits were $6.4 \mu \mathrm{g} \mathrm{N}{ }^{-1}$, $6.2 \mu \mathrm{g} \mathrm{Nl}^{-1}, 3.0 \mu \mathrm{g} \mathrm{Nl}^{-1}$ and $10.1 \mu \mathrm{g} \mathrm{Pl}^{-1}$ for $\mathrm{NH}_{4}^{+}, \mathrm{NO}_{3}^{-}$, $\mathrm{NO}_{2}^{-}$and $\mathrm{PO}_{4}^{3-}$ respectively. The coefficients of variation (C.V.) for eight replicate standards were $1.4 \%, 4.5 \%, 1.6 \%$ and $1.4 \%$ respectively. Total dissolved nitrogen $\left(\mathrm{TN}_{(\mathrm{aq})}\right)$ on snow and ice samples was analyzed on a Shimadzu TOC-V CSN analyzer with TNM-1 nitrogen measuring unit. The detection limit was $3.1 \mu \mathrm{g} \mathrm{N}^{-1}$, with a precision of $1.4 \%$. Unfortunately, $\mathrm{TN}_{(\mathrm{aq})}$ was not carried out on cryoconite water samples due to loss of samples.

Cryoconite-bound $\mathrm{NH}_{4}^{+}\left(\mathrm{NH}_{4}^{+}(\mathrm{s}), \mathrm{NO}_{3}^{-}\left(\mathrm{NO}_{3}^{-}(\mathrm{s})\right.\right.$ ) and $\mathrm{NO}_{2}^{-}\left(\mathrm{NO}_{2}^{-}(\mathrm{s})\right.$ were extracted from cryoconite using a $1 \mathrm{M}$ $\mathrm{KCl}$ method (Telling et al., 2011). Extracts were analysed on a Bran and Luebbe AutoAnalyzer 3 as described above. The detection limits were $0.7 \mu \mathrm{g} \mathrm{N} \mathrm{g}^{-1}$ dry sediment, $1.4 \mu \mathrm{g} \mathrm{N} \mathrm{g}^{-1}$ dry sediment and $0.03 \mu \mathrm{g} \mathrm{Ng}^{-1}$ dry sediment for $\mathrm{NH}_{4+(\mathrm{s})}, \mathrm{TON}_{(\mathrm{s})}$ and $\mathrm{NO}_{2}^{-}$(s) respectively.

Duplicate dried cryoconite samples were analyzed for total nitrogen (TN) on a EuroVector EA3000 Elemental Analyzer. Precision of duplicate TN analyses for the $17 \mathrm{~km}$ to $51 \mathrm{~km}$ sites (all $>0.4 \% \mathrm{TN}$ ) was $\leq 6.3 \%$. Precisions of the lower concentration $2 \mathrm{~km}$ to $7.5 \mathrm{~km}$ sites (all $<0.17 \%$ $\mathrm{TN}$ ) ranged from $10.5 \%$ to $40.9 \%$, with a detection limit of $100 \mu \mathrm{g} \mathrm{N} \mathrm{g}{ }^{-1}$.

\subsection{Acetylene assays (nitrogenase activity)}

Rates of nitrogenase activity were measured using the acetylene assay (Stewart et al., 1967), adapted for field sampling and later laboratory ethylene analyses using the method of Telling et al. (2011). Acetylene assays were carried out in four separate cryoconite holes at each of the $2 \mathrm{~km}$ to $51 \mathrm{~km}$ sites, at four points in the slush zone at $79 \mathrm{~km}$, at three points on the debris apron at $0 \mathrm{~km}$, and at three different times in cryoconite holes at the $2 \mathrm{~km}$ alternate site (12-13 June, 23-24 July and 27-28 July 2010). At each individual hole or sample point, duplicate acetylene amended assays were carried out along with one control with no acetylene added. The latter was used to check for any background ethylene production during the incubations. Fourteen additional serum bottles (five on the walking traverse, five on the helicopter traverse, four at the $2 \mathrm{~km}$ alternate site) were filled with $15 \mathrm{ml}$ of $0.2 \mu \mathrm{m}$ filtered MQ water (blank controls) and incubated and analysed as described above. At all bare ice sites ( $2 \mathrm{~km}$ to $51 \mathrm{~km}, 2 \mathrm{~km}$ alternate site), assays were carried out on mixtures of cryoconite debris and cryoconite water, using similar cryoconite thicknesses to those within the holes. At the $0 \mathrm{~km}$ site, debris with no water was used in the assays to replicate in situ conditions. At the $79 \mathrm{~km}$ site, slush containing dispersed cryoconite particles was used, again to replicate in situ conditions. Incubations were carried out for $24 \mathrm{~h}$, and subsamples of headspace gas immediately removed into preevacuated vials for later laboratory analysis.

Gas samples were stored refrigerated for up to two months prior to analysis by gas chromatography following the methods of Telling et al. (2011). Daily standards of 100 ppm ethylene (Sigma) gave precisions $<8 \%$. The detection limit was $4.2 \mu$ moles $\mathrm{C}_{2} \mathrm{H}_{4} \mathrm{~m}^{-2}$ day $^{-1}$. Rates were normalised to both the surface area of cryoconite in the bottles and to the dry weight of cryoconite $\left(\mu\right.$ moles $\mathrm{C}_{2} \mathrm{H}_{4} \mathrm{~g}^{-1}$ day $^{-1}$ ) after drying and reweighing replicate cryoconite samples from each site. The potential nitrogen fixed in the assays $\left(\mathrm{N}_{2} \mathrm{fix}_{\text {daily }}\right)$ was estimated by Eq. (1):

$\mathrm{N}_{2}$ fix $_{\text {daily }}=\mathrm{C}_{2} \mathrm{H}_{4} \times 1 / 3 \times 28$

where $\mathrm{C}_{2} \mathrm{H}_{4}$ is the amount of ethylene produced in the vials (after first correcting for ethylene dissolution in water using the equations of Breitbarth et al. (2004)), $\times 1 / 3$ converts $\mu$ moles ethylene to $\mu$ moles nitrogen assuming a 3:1 molar ratio between the two (Stewart et al., 1967), and $\times 28$ converts moles of dinitrogen to mass.

\subsection{Net ecosystem production}

Net ecosystem production (NEP) was measured in cryoconite holes at four different times at the $2 \mathrm{~km}$ alternate site (4-5 June, 8-9 June, 12-15 June, and 15-16 June 2010). NEP is the net balance of gross photosynthesis and respiration of an ecosystem. NEP was measured by incubating glass bottles filled with cryoconite and water for $24 \mathrm{~h}$ within cryoconite holes. Changes in dissolved inorganic carbon in the incubation bottles were measured directly after the incubations had finished on the surface of the glacier using a PP systems EGM-4 infrared $\mathrm{CO}_{2}$ meter, following the methods of Hodson et al. (2010a) and Telling et al. (2010). NEP measurements for transect sites have already been reported in Stibal et al. (2012). 


\subsection{DNA extraction and quantitative PCR}

Extraction of DNA from one pooled sample from each transect site was performed using the PowerSoil DNA Isolation Kit (MO BIO Laboratories, Carlsbad, CA, USA) according to the manufacturer's instructions. $300 \mathrm{mg}$ (wet weight) of sediment was used for each extraction, and a blank containing no sediment was extracted in parallel.

The relative abundance of the nitrogenase reductase gene (nifH) in the DNA extracts from along the transect was determined using quantitative PCR with three sets of primers specific for two groups of cyanobacteria (Trichodesmium-like and heterocystous) and Gammaproteobacteria (Table 1; Church et al., 2005). These primers were chosen to distinguish between the main groups of potential nitrogen fixers in the samples. The 10- $\mu$ qPCR reactions contained $1 \mu \mathrm{l}$ of DNA extract, $5 \mu$ of $2 \times$ SsoFast EvaGreen Supermix (Bio-Rad, Hercules, CA, USA) and $1 \mu$ of forward and reverse primer (final concentration $0.5 \mu \mathrm{M}$ ). A MiniOpticon detection system (Bio-Rad, Hercules, CA, USA) was used for detection of amplified PCR products using the following thermal cycling conditions: initial denaturation at $95^{\circ} \mathrm{C}$ for $5 \mathrm{~min}$ and $45 \mathrm{cycles}$ of $95^{\circ} \mathrm{C}$ for $15 \mathrm{~s}, 60^{\circ} \mathrm{C}$ for $30 \mathrm{~s}$ and $72^{\circ} \mathrm{C}$ for $30 \mathrm{~s}$, followed by melting curve analysis to ensure that primer-dimers were not formed. Three replicates were analysed for each sample and blank. No nifH copies were detected in any of the blanks. No nifH standards were run; hence, the qPCR data are only used to compare the relative abundance of the nifH gene within the respective groups along the transect. The data cannot therefore be used to assess differences in the relative abundance of the nifH gene from different microbial groups at the same sites.

\subsection{Nitrogen mass balance estimates}

Annual inputs of nitrogen (in units of $\mathrm{kg} \mathrm{Nyr}^{-1}$ ) from nitrogen fixation, precipitation and icemelt were estimated for the three zones (marginal, glacier, ice sheet) of the transect (Fig. 2), assuming that the transect is $1 \mathrm{~km}^{2}$ wide.

Nitrogen inputs from precipitation were estimated from Eq. (2):

$\mathrm{N}_{\text {precip }}=$ precip $_{\text {annual }} \times \mathrm{N}_{\text {snow }} \times$ area

where precipannual is the estimated annual precipitation across the transect sites $\left(400 \mathrm{~kg} \mathrm{~m}^{-2} \mathrm{yr}^{-1}\right.$, with $94 \%$ in the form of snow; Ettema et al., 2009), $\mathrm{N}_{\text {snow }}$ is the average concentration of $\mathrm{NO}_{3}^{-}$(aq) in fresh snow (in $\mathrm{kg} \mathrm{N}^{-1}$, from Sect. 3.2), and area is the area of each of the three zones $\left(0.1 \mathrm{~km}^{2}, 7.4 \mathrm{~km}^{2}\right.$ and $71.5 \mathrm{~km}^{2}$ for the marginal, glacier, and ice sheet zones respectively).

The nitrogen input from icemelt in each of the three zones ( $\mathrm{N}_{\text {icemelt }}$ ) was calculated from Eq. (3):

$\mathrm{N}_{\text {icemelt }}=$ ablation $\times \mathrm{N}_{\text {ice }}$

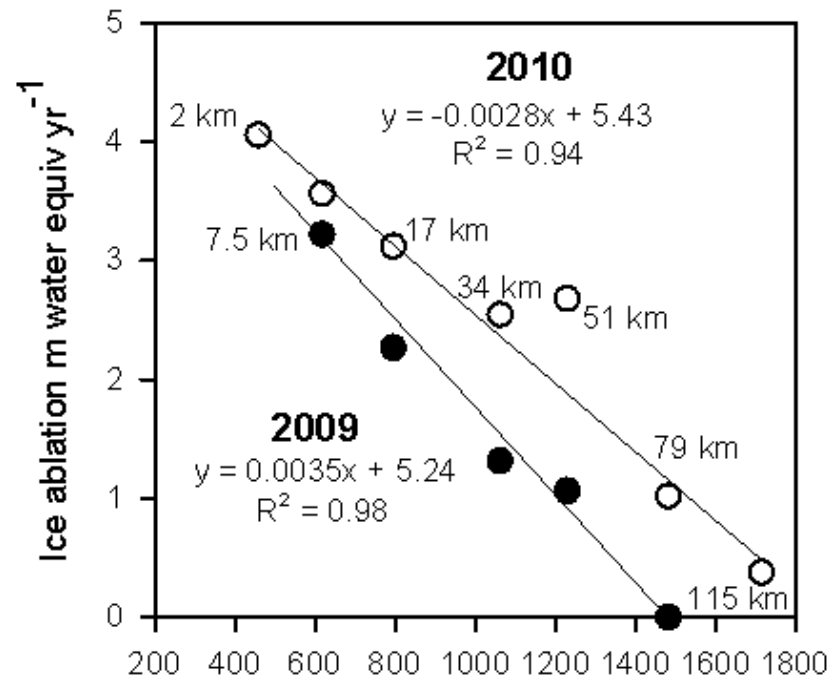

Altitude $\mathrm{m}$

Fig. 3. Ice ablation data. Estimated annual ice ablation at transect sites for 2009 (solid circles) and 2010 (open circles) melt seasons. There is an approximately linear relationship between site altitude and ablation in both seasons.

where ablation is the amount of water (in $\mathrm{kg}$ ) that annually ablates from each zone, calculated as follows. First, the annual ablation for each site is estimated for all transect sites using the best fit linear equations in Fig. 3 for the 2009 and 2010 melt seasons. Second, the values of ablation for adjacent sites are averaged (termed here ablation average $n-n+1_{1}$ ). Third, the amount of ablation in the area between adjacent transect sites is calculated using Eq. (4):

ablation $_{n-n+1}=$ ablation $_{\text {average } n-n+1} \times$ area $_{n}$ to $n+1$

where $\operatorname{area}_{n}$ to $n+1$ is the area between adjacent sites (in $\mathrm{km}^{2}$ ). Finally, the total ablation for each zone is calculated from Eq. (5) by summing the ablation of all subareas within each zone (e.g. summing the $2 \mathrm{~km}$ to $4 \mathrm{~km}, 4 \mathrm{~km}$ to $5.7 \mathrm{~km}$ and $5.7 \mathrm{~km}$ to $7.5 \mathrm{~km}$ ablation rates for the glacier zone):

ablation $=\Sigma\left(\right.$ ablation $_{n-n+1}+$ ablation $\left._{n+1-n+2 \ldots \ldots \ldots . .}\right)$.

The estimated nitrogen input from nitrogen fixation for each of the three zones $\left(\mathrm{N}_{2} \mathrm{fix}\right)$ is estimated using Eq. (6):

$\mathrm{N}_{2}$ fix $=\mathrm{N}_{2} \mathrm{fix}_{\mathrm{av}} \times$ mass $_{\text {cryoconite }} \times$ aea $\times t$

where $\mathrm{N}_{2} \mathrm{fix}_{\mathrm{av}}$ is the mean daily nitrogen fixation rate for

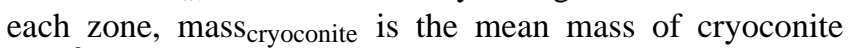
$\mathrm{km}^{-2}$ in each of the three zones (using data from Table 2) and $t$ is the typical melt season length in the marginal and glacier zones (120 days) and ice sheet zone (110 days) (from Wang et al., 2007).

The estimated annual microbial nitrogen uptake due to net growth in each zone is calculated using Eq. (7):

$\mathrm{N}_{\mathrm{NEP}}=\mathrm{NEP} \times 14 /(12 \times 6.6) \times$ mass $_{\text {cryoconite }} \times t$ 
Table 1. Primer sets used for qPCR of the nifH gene from the samples (from Church et al., 2005).

\begin{tabular}{lllc}
\hline name & target & sequence $\left(5^{\prime}-3^{\prime}\right)$ & length (bp) \\
\hline Het105F & heterocystous cyanobacteria & CGGTTTCCGTGGTGTACGTT & \\
Het158R & AATACCACGACCCGCACAAC & 72 \\
\hline Tri217F & \multirow{2}{*}{ Trichodesmium } & GACGAAGTATTGAAGCCAGGTTTC & \\
Tri284R & & CGGCCAGCGCAACCTA & 83 \\
\hline$\gamma 104 \mathrm{~F}$ & \multirow{2}{*}{ Gammaproteobacteria } & TTGGCTTTGGCGACATCAA & 73 \\
$\gamma 152 \mathrm{R}$ & & ACGACCAGCACAGCCAACTC & \\
\hline
\end{tabular}

Table 2. Additional NEP and cryoconite coverage data used for mass balance calculations (Sect. 2.6).

\begin{tabular}{|c|c|c|c|c|c|}
\hline Transect station & Date & $\begin{array}{l}\text { Distance } \\
\text { from ice } \\
\text { sheet margin } \\
(\mathrm{km})\end{array}$ & $\begin{array}{l}\mathrm{NEP}^{1} \\
\mu \mathrm{g} \mathrm{Cg}^{-1}, \mathrm{~d}^{-1}\end{array}$ & $\begin{array}{l}\text { Mean } \\
\text { cryoconite } \\
\text { mass }^{1} \mathrm{~g} \mathrm{~m}^{-2}\end{array}$ & Reference \\
\hline Marginal zone & $\begin{array}{r}\text { 1 September } 2008 \text { to } 2 \text { September } 2008 \\
5 \text { August } 2010 \text { to } 6 \text { August } 2010\end{array}$ & $\begin{array}{l}0 \text { to } 0.1 \\
0 \text { to } 0.1\end{array}$ & $\begin{array}{r}0.12 \pm 0.02 \\
1.9 \pm 0.9\end{array}$ & $\begin{array}{r}736 \\
3775\end{array}$ & $\begin{array}{l}\text { Hodson et al. (2010b) } \\
\text { Stibal et al. (2012) }\end{array}$ \\
\hline Glacier zone & $\begin{array}{r}22 \text { August } 2008 \text { to } 1 \text { September } 2008 \\
5 \text { August } 2010 \text { to } 6 \text { August } 2010 \\
4 \text { June } 2010 \text { to } 15 \text { June } 2010\end{array}$ & 2 to $\begin{array}{r}2 \\
2.5 \\
2\end{array}$ & $\begin{array}{r}-0.18 \pm 0.38 \\
4.1 \pm 3.0 \\
2.8 \pm 1.1\end{array}$ & $\begin{array}{l}66.5 \\
55.0 \\
\mathrm{ND}^{2}\end{array}$ & $\begin{array}{l}\text { Hodson et al. (2010b) } \\
\text { Stibal et al. (2012) } \\
\text { This study }\end{array}$ \\
\hline Ice sheet zone & 1 August 2010 to 2 August 2010 & 17 to 51 & $10.2 \pm 10.4$ & 165 & Stibal et al. (2012) \\
\hline
\end{tabular}

${ }^{1}$ Error bars are $\pm 1 \sigma .{ }^{2}$ As this site is approximately the same as Hodson et al. (2010b), we assume same mean cryoconite mass of $66.6 \mathrm{~g} \mathrm{~m}^{-2}$.

where $\mathrm{N}_{\mathrm{NEP}}$ is the estimated nitrogen requirement of balanced microbial growth, NEP is the mean rate of net microbial carbon production in each zone (from data in Table $2), \times 14 / 12$ converts moles of carbon to moles of nitrogen, dividing by 6.6 assumes a 1:6.6 ratio between nitrogen and carbon in microbial cells (after Redfield et al., 1963), and mass $_{\text {cryoconite }}$ is the mean measured mass of cryoconite at each site (from Table 2).

\section{Results}

\subsection{Ice ablation}

Annual ice ablation for the 2010 melt season ranged from $4.06 \mathrm{~m} \mathrm{yr}^{-1}$ (water equivalent) at the $2 \mathrm{~km}$ site to $1.06 \mathrm{~m} \mathrm{yr}^{-1}$ at the $79 \mathrm{~km}$ site (Fig. 3). Annual ice ablation in the 2009 melt season was lower than in 2010, ranging from $3.22 \mathrm{~m} \mathrm{yr}^{-1}$ at the $7 \mathrm{~km}$ site to zero ablation at the $79 \mathrm{~km}$ site (there were insufficient data available from the $2 \mathrm{~km}$ site in the 2009 season) (Fig. 3). There were approximately linear relationships between altitude and ice ablation in both years $\left(r^{2}=0.94\right.$ and $r^{2}=0.98$ for the 2010 and 2009 ablation seasons respectively; Fig. 3).

\subsection{Nutrients}

The mean $\mathrm{NO}_{3}^{-}$(aq) concentration for all ice samples along transect was $8.6 \pm 1.7 \mu \mathrm{g} \mathrm{N}^{-1}(1 \sigma)(n=9)$ (Fig. 4). The $\mathrm{NO}_{3}^{-}$(aq) concentrations in ice at the marginal, glacier and ice sheet zones were $6.8 \mu \mathrm{gNl}^{-1} \quad(1 \sigma) \quad(n=1)$, $9.3 \pm 2.2 \mu \mathrm{g} \mathrm{N}^{-1}(1 \sigma)(n=4)$ and $8.4 \pm 1.1 \mu \mathrm{g} \mathrm{Nl}^{-1}(1 \sigma)$ $(n=4)$ respectively. The mean $\mathrm{NO}_{3}^{-}(\mathrm{aq})$ concentration of fresh snow was greater than that of ice at $14.3 \pm 4.3 \mu \mathrm{g} \mathrm{N} 1^{-1}$ $(1 \sigma)$ (Fig. 4). $\mathrm{NH}_{4}^{+}$(aq), $\mathrm{NO}_{2}^{-}$(aq) and $\mathrm{PO}_{4}^{3-}$ (aq) were below detection in all snow and ice samples. Procedural blanks $(n=4)$ for snow and ice samples were below detection for $\mathrm{NO}_{3 \text { (aq) }}^{-} \mathrm{NH}_{4}^{+}$(aq) $^{-} \mathrm{NO}_{2}^{-}$(aq) and $\mathrm{PO}_{4}^{3-}{ }_{(\mathrm{aq})}$.

There was a strong correlation between $\mathrm{NO}_{3}^{-}(\mathrm{aq})$ and $\left.\mathrm{TN}_{(\mathrm{aq}}\right)$, with $94.1 \pm 20.7 \% \quad(1 \sigma) \quad(n=14)$ and $100.9 \pm 23.7 \%(1 \sigma)(n=3)$ of $\mathrm{TN}_{(\mathrm{aq})}$ in the form of DIN in ice and snow respectively (Fig. 4).

Mean $\mathrm{NH}_{4}^{+}(\mathrm{aq})$ and $\mathrm{NO}_{3}^{-}$(aq) concentrations in cryoconite holes along the transect ranged from below detection $\left(<6.4 \mu \mathrm{g} \mathrm{N}^{-1} \quad \mathrm{NH}_{4}^{+}, \quad<6.2 \mu \mathrm{g} \mathrm{Nl}^{-1} \quad \mathrm{NO}_{3}^{-}\right)$ to $11.4 \pm 3.2 \mu \mathrm{g} \mathrm{N}^{-1} \quad \mathrm{NH}_{4}^{+}(\mathrm{aq})$ and $11.3 \pm 0.9 \mu \mathrm{g} \mathrm{N}^{-1}$ $\mathrm{NO}_{3}^{-}$(aq) (Fig. 5a). Mean concentrations of $\mathrm{NO}_{3}^{-}$(aq) were relatively constant at the $79 \mathrm{~km}, 51 \mathrm{~km}, 34 \mathrm{~km}$ and $18 \mathrm{~km}$ sites, ranging from 10.5 to $11.3 \mu \mathrm{g} \mathrm{N}{ }^{-1}$. The latter concentrations were higher than the typical $\mathrm{NO}_{3(\mathrm{aq})}^{-}$concentrations of ice $(8.6 \pm 1.7(1 \sigma)$; Fig. 4). There was a decrease in mean 


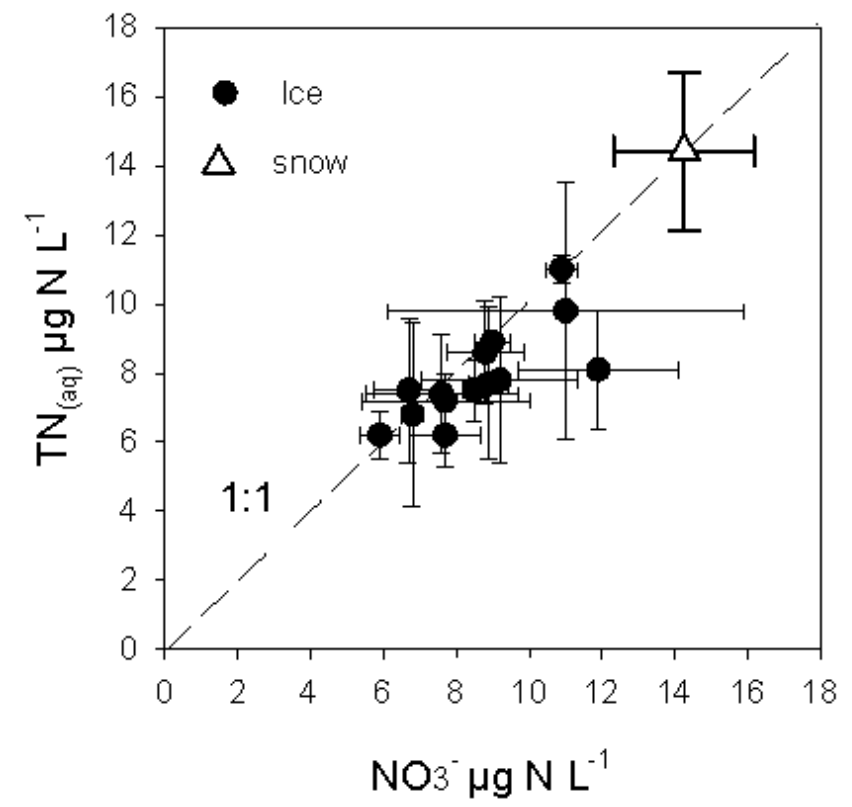

Fig. 4. $\mathrm{NO}_{3}^{-}$(aq) versus total dissolved nitrogen $\left(\mathrm{TN}_{(\mathrm{aq})}\right)$ in ice and snow samples along the transect. There is a near 1:1 relationship between $\mathrm{NO}_{3}^{-}(\mathrm{aq})$ and $\mathrm{TN}_{(\mathrm{aq})}$ indicating that organic nitrogen is a relatively minor component of both ice and snow along the transect. Error bars are $\pm 1 \sigma$.

$\mathrm{NO}_{3}^{-}$(aq) concentrations from $10.9 \mu \mathrm{g} \mathrm{N} l^{-1}$ at the $17 \mathrm{~km}$ site to $<6.2 \mu \mathrm{g} \mathrm{N}^{-1}$ at the 2, 4 and $5.5 \mathrm{~km}$ sites (Fig. 5a). $\mathrm{NH}_{4}^{+}$(aq) was detected only at the $4 \mathrm{~km}$ and $7.5 \mathrm{~km}$ sites (Fig. 5a). $\mathrm{NO}_{2}^{-}$(aq) and $\mathrm{PO}_{4}^{3-}$ (aq) were below detection in all samples $\left(<3.0 \mu \mathrm{g} \mathrm{N}^{-1} \mathrm{NO}_{2}^{-}\right.$and $<10.1 \mu \mathrm{g} \mathrm{Pl}^{-1} \mathrm{PO}_{4}^{3-}$ ).

Cryoconite-bound $\mathrm{NH}_{4}^{+}(\mathrm{s})$ ranged from $<0.7$ to $12.6 \mu \mathrm{g} \mathrm{Ng}^{-1}$ (Fig. 5b). There was a trend of increasing $\mathrm{NH}_{4}^{+}$(s) with increasing distance into the GrIS (Fig. 5b). $\mathrm{NH}_{4}^{+}$(s) was undetectable $\left(<0.7 \mu \mathrm{g} \mathrm{N} \mathrm{g}^{-1}\right)$ from $0 \mathrm{~km}$ to $5.7 \mathrm{~km}$, first detected at $7.5 \mathrm{~km}$ and then increased to a maximum of $12.6 \pm 1.8 \mu \mathrm{g} \mathrm{g} \mathrm{g}^{-1}(1 \sigma)$ at $51 \mathrm{~km}$ (Fig. 5b). $\mathrm{NO}_{3}^{-}$(s) was only detected in one of the three samples at the $0 \mathrm{~km}$ site $\left(2.2 \mu \mathrm{g} \mathrm{N} \mathrm{g}^{-1}\right)$ with all samples at all other sites $<1.4 \mu \mathrm{g} \mathrm{N} \mathrm{g}^{-1} \mathrm{NO}_{3}^{-}$(s) (Fig. 5b). $\mathrm{NO}_{2}^{-}$(s) was not detected at any site (all $\left.<0.03 \mu \mathrm{g} \mathrm{N} \mathrm{g}^{-1}\right)$.

Total organic carbon (TOC)/TN ratios in cryoconite increased from the $2 \mathrm{~km}$ site $\left(8.2 \pm 3.9 \mathrm{mg} \mathrm{N} \mathrm{g}^{-1}, 1 \sigma\right)$ to the $17 \mathrm{~km}$ site $\left(13.5 \pm 0.4 \mathrm{mg} \mathrm{N} \mathrm{g}^{-1}, 1 \sigma\right)$, and diminished to $11.6 \pm 0.16(1 \sigma)$ at the $51 \mathrm{~km}$ site (Fig. $5 \mathrm{~b}$ ) (TOC data are from Stibal et al., 2012.). Maximum estimates for TOC/TN ratios at the $0 \mathrm{~km}$ site (since TN was below detection) were $\leq 4.8, \leq 7.8$ and $\leq 9.8$. There was a significant correlation between total organic carbon (TOC) and $\mathrm{NH}_{4}^{+}(\mathrm{s})(r=0.986$, $n=9, \quad p<0.01$; Pearson's correlation, two-tailed t-test; Fig. 5c). There were also significant correlations between TN and TOC $(r=0.989, n=9, p<0.01$; Pearson's correlation, two tailed t-test (not shown) and TN and cryoconite-bound
$\mathrm{NH}_{4}^{+}$(s) $(r=0.993, n=9, p<0.01$; Pearson's correlation, two-tailed t-test) (not shown).

\subsection{Nitrogen fixation activity and nitrogenase gene abundance}

Rates of nitrogen fixation ranged from below detection to $119.6 \pm 25.6 \mu$ moles $\mathrm{C}_{2} \mathrm{H}_{4} \mathrm{~g}^{-1}$ day $^{-1}$ (equivalent to $<$ $4.2 \mu$ moles to $16.3 \mu$ moles $\mathrm{C}_{2} \mathrm{H}_{4} \mathrm{~m}^{-2}$ day $^{-1}$ ) (Fig. 5d). Ethylene production in control bottles with no acetylene added was always below the detection limit $(<4.2 \mu$ moles $\mathrm{C}_{2} \mathrm{H}_{4} \mathrm{~m}^{-2}$ day $^{-1}$ ) with a mean of $1.0 \pm 1.4 \mu$ moles $\mathrm{C}_{2} \mathrm{H}_{4}$ $\mathrm{m}^{-2}$ day $^{-1}(1 \sigma, n=39)$. Nitrogen fixation was detected at the $0 \mathrm{~km}, 2 \mathrm{~km}$ and $5.7 \mathrm{~km}$ sites, but not at distances of $7.5 \mathrm{~km}$ or greater into the GrIS (Fig. 5d), or at the alternate $2 \mathrm{~km}$ site. Nitrogen fixation was detected only when both DIN and $\mathrm{NH}_{4}^{+}$(s) were below detection $\left(<6.4 \mu \mathrm{g} \mathrm{N}^{-1} \mathrm{NH}_{4}^{+}\right.$(aq), $<6.2 \mu \mathrm{g} \mathrm{N}^{-1} \mathrm{NO}_{3}^{-}$(aq) and $<$ $0.7 \mu \mathrm{g} \mathrm{N} \mathrm{g}^{-1} \mathrm{NH}_{4}^{+}$(s) (Fig. 6a, b).

Nitrogenase reductase genes were detected at all sites using all three primer sets (Fig. 5e), and similar trends in their relative abundance along the transect were observed. The relative abundance of nifH from heterocystous cyanobacteria increased with distance up to $34 \mathrm{~km}$ and then decreased again, while both the Trichodesmiumlike and the Gammaproteobacteria nitrogenase gene abundances had peaks at $51 \mathrm{~km}$ inland (Fig. 5e). This is in contrast to measured rates of acetylene reduction, which were only detected in the first $5.7 \mathrm{~km}$ (Fig. 5d). There was no significant correlation between rates of acetylene reduction and the relative abundance of the heterocystous cyanobacteria nifH gene $(r=-0.333, p=0.381, n=9)$, the Trichodesmium-like nifH gene $(r=-0.265, p=0.491, n=9)$ or the Gammaproteobacteria nifH gene $(r=-0.464, p=$ $0.208, n=9$ ) (where $r$ refers to the Pearson product-moment correlation coefficient).

\subsection{Nitrogen mass balance estimates}

Across the entire $79 \mathrm{~km}^{2}$ of the transect, icemelt provides an estimated $1451 \pm 423 \mathrm{~kg} \mathrm{Nyr}^{-1}$, precipitation provides $408.1 \mathrm{~kg} \mathrm{Nyr}^{-1}$, and nitrogen fixation just $1.4 \pm 0.7 \mathrm{~kg} \mathrm{~N} \mathrm{yr}^{-1}$ (Fig. 7a). The estimated input of nitrogen from nitrogen fixation over the transect is therefore an estimated $0.07 \%$ of the combined nitrogen fluxes of icemelt and precipitation. Although the precipitation flux is based on the concentration of just three samples of fresh snow $\left(14.3 \pm 4.3 \mu \mathrm{g} \mathrm{N}^{-1}\right.$; Sect. 3.2), these concentrations are in the range of previous estimates of the $\mathrm{NO}_{3}^{-}$concentration of fresh snow on the GrIS (mean of $16.9 \mu \mathrm{g} \mathrm{N}^{-1}$; Fischer et al., 1998).

Nitrogen fixation does have the potential, however, to be a significant source of nitrogen (relative to icemelt and precipitation) in the marginal zone (Fig. 7b, d). The estimated input of nitrogen from nitrogen fixation onto the $0.1 \mathrm{~km}^{2}$ marginal 

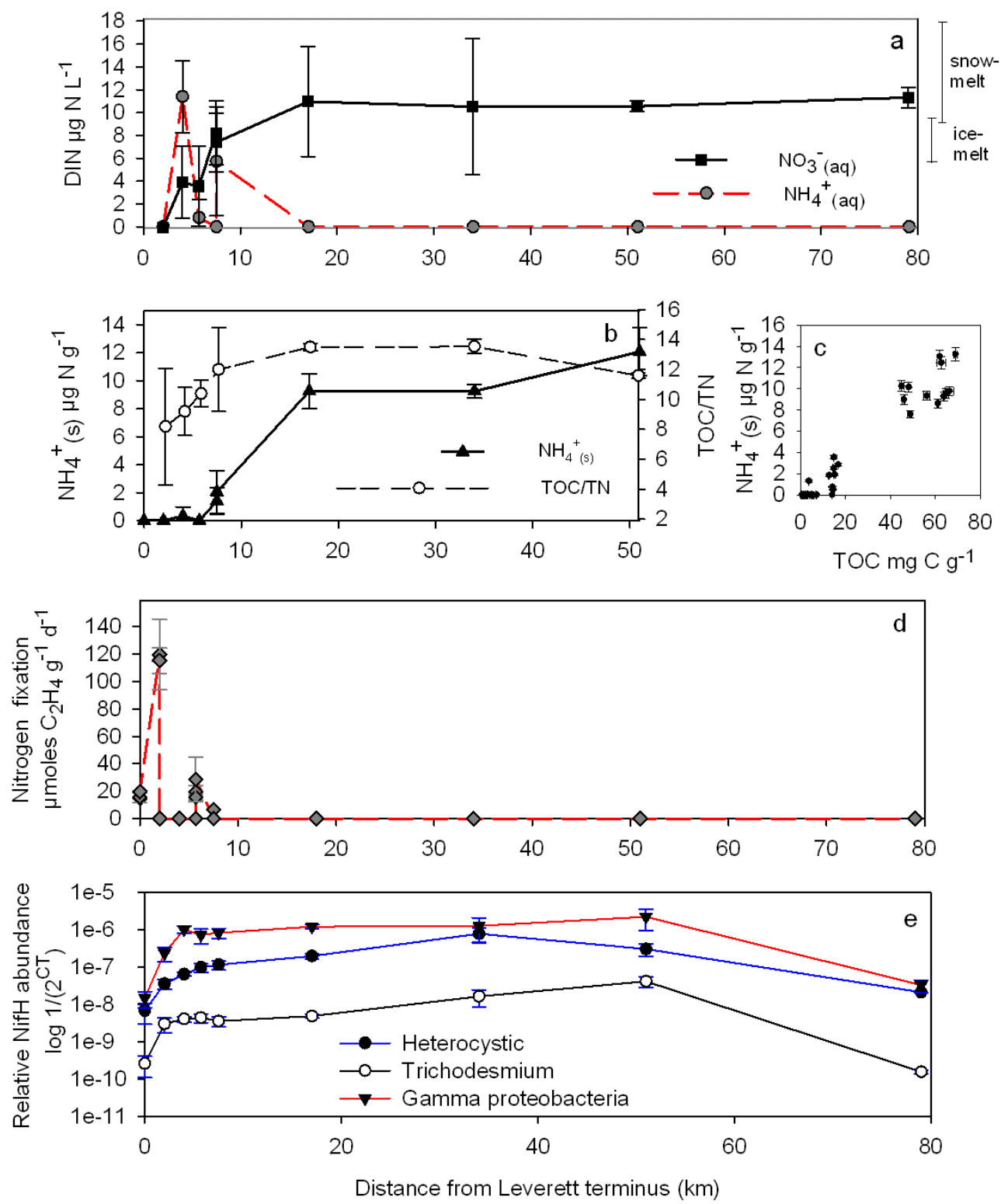

Fig. 5. Cryoconite hole nitrogen chemistry and microbial activity along the transect. (a) Dissolved inorganic nitrogen (DIN) in cryoconite holes. The mean icemelt and snowmelt DIN concentrations $( \pm 1 \sigma)$ are shown on the right-hand side of the figure for comparison. (b) Cryoconite-bound $\mathrm{NH}_{4}^{+}$(s) and ratio of TOC/TN (total organic carbon/total nitrogen) in cryoconite holes. Only the first $51 \mathrm{~km}$ of the transect is shown as there was insufficient cryoconite debris at $79 \mathrm{~km}$ for solid phase analysis (c). Cryoconite total organic carbon (TOC) vs. cryoconite-bound $\mathrm{NH}_{4}^{+}$(s) (d). Nitrogen fixation (acetylene assay) in cryoconite holes. (e) Relative abundance of nifH genes from Gammaproteobacteria, Trichodesmium-type and heterocystic bacteria. In the absence of nifH standards, the qPCR data can only be used to compare the relative abundance of the nifH gene within respective groups along the transect. The data cannot be used to assess differences in the relative abundance of the nifH gene from different microbial groups at the same sites. Error bars are $\pm 1 \sigma$.

zone $\left(0.77 \pm 0.11 \mathrm{~kg} \mathrm{~N} \mathrm{yr}^{-1}\right)$ was $22.8 \%$ of the combined inputs of nitrogen from precipitation $\left(0.6 \mathrm{~kg} \mathrm{~N} \mathrm{~km}^{-2} \mathrm{yr}^{-1}\right)$, and icemelt $\left(2.77 \pm 0.23 \mathrm{~kg} \mathrm{~N} \mathrm{yr}^{-1}\right)$.

The total flux of nitrogen from nitrogen from nitrogen fixation onto the $7.4 \mathrm{~km}$ glacier zone $\left(0.62 \pm 0.73 \mathrm{~kg} \mathrm{~N} \mathrm{yr}^{-1}\right)$ was similar to the annual estimated nitrogen fixation input into the marginal zone (Fig. 7b). The input of nitro- gen in the glacier zone was however just $0.2 \%$ of the combined inputs of nitrogen from precipitation $\left(42.2 \mathrm{~kg} \mathrm{~N} \mathrm{yr}^{-1}\right)$ and icemelt $\left(267 \pm 25.6 \mathrm{~kg} \mathrm{Nyr}^{-1}\right)$ (Fig. 7e). When normalised, area mean rates in the glacier zone $(0.08 \pm 0.10)$ were two orders of magnitude lower than in the marginal zone $\left(7.7 \pm 1.1 \mathrm{~kg} \mathrm{~N} \mathrm{~km}^{-2} \mathrm{yr}^{-1}\right)$. 

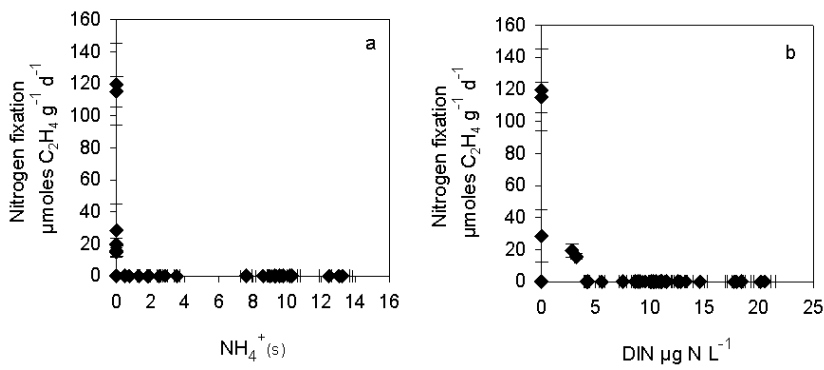

Fig. 6. Scatter plot showing relationships between chemistry and nitrogen fixation (a). Cryoconite-bound $\mathrm{NH}_{4}^{+}$(s) vs. nitrogen fixation in cryoconite holes along the transect (b). Dissolved inorganic nitrogen (DIN) vs. nitrogen fixation in cryoconite holes along the transect. Error bars are $\pm 1 \sigma$.

The estimated input of nitrogen from nitrogen fixation onto the $71.5 \mathrm{~km}^{2}$ ice sheet zone was zero (Fig. 7f). Estimated inputs of nitrogen from precipitation and icemelt onto the ice sheet zone were $408 \mathrm{~kg} \mathrm{Nyr}^{-1}$ and $1181 \pm 423 \mathrm{~kg} \mathrm{~N} \mathrm{yr}^{-1}$, respectively.

Mean rates of NEP in the marginal zone $\left(7.1 \pm 10.6 \mathrm{~kg} \mathrm{Nyr}^{-1}\right)$ and ice sheet zone $\left(2172 \pm 2602 \mathrm{~kg} \mathrm{Nyr}^{-1}\right)$ exceeded the combined inputs of precipitation and icemelt, although the ice sheet zone NEP values were highly variable (Fig. 7d, f). Mean rates of NEP in the glacier zone $\left(19.2 \pm 20.0 \mathrm{~kg} \mathrm{~N} \mathrm{yr}^{-1}\right)$ were lower than inputs from both ice melt and precipitation (Fig. 7e). Using paired measurements from the same cryoconite holes of estimates of nitrogen fixation (from this study) and NEP (from Stibal et al., 2012), we estimate that nitrogen fixation was an average of $6.4 \pm 1.7 \%, 2.0 \pm 6.6 \%$ and $0 \%$ of the estimated mean microbial nitrogen demand $\left(\mathrm{N}_{\mathrm{NEP}}\right)$ in the marginal, glacier and ice sheet zones respectively (Fig. 7c).

\section{Discussion}

\subsection{Active nitrogen fixation in the marginal and glacier zones}

Positive acetylene reduction assays in the marginal and glacier zones of this study (Fig. 5) are indicative of nitrogenase activity, demonstrating the potential for nitrogen fixation. The measured rates of acetylene reduction in cryoconite $\left(<4.2 \mu\right.$ moles $\mathrm{C}_{2} \mathrm{H}_{4} \mathrm{~m}^{-2}$ day ${ }^{-1}$ to $16.3 \mu$ moles $\mathrm{C}_{2} \mathrm{H}_{4} \mathrm{~m}^{-2}$ day $^{-1}$ ) were within the range of those previously documented on Svalbard valley glaciers $(<2.0$ to $99.9 \mu$ moles $\mathrm{C}_{2} \mathrm{H}_{4} \mathrm{~m}^{-2}$ day $^{-1}$; Telling et al., 2011).

Nitrogen fixation within the marginal zone is also consistent with annual mass balance calculations (Sect. 3.4). The mean estimated annual $\mathrm{N}_{\mathrm{NEP}}$ in the marginal zone exceeded estimated annual inputs of nitrogen from precipitation and icemelt (Fig. 7d) suggesting a potential annual shortfall in nitrogen for net microbial growth. Nitrogen fixation was there- fore likely making up a shortfall in the microbial nitrogen budget at the $0 \mathrm{~km}$ site. Nitrogen fixation at the $0 \mathrm{~km}$ site may represent an important process in the primary colonization of predominantly inorganic debris $\left(<1 \mathrm{mg} \mathrm{g}^{-1} \mathrm{TOC}\right.$, Stibal et al., 2012). Cryoconite at the $0 \mathrm{~km}$ site likely derives from subglacial or lateral moraine debris, and the microbial ecology at this site may be analogous to the primary colonization of moraines adjacent to glaciers and ice sheets (Schmidt et al., 2008). The hourly areal rates of potential nitrogen fixation in the cryoconite at the $0 \mathrm{~km}$ site $\left(2.6 \pm 2.3 \mu \mathrm{g} \mathrm{N} \mathrm{m}^{-2} \mathrm{~h}^{-1}\right.$; estimated by dividing the areal nitrogen fixation rates from this study by 24) were in the range of recently colonised glacial moraine in the Andes $\left(0.8 \mu \mathrm{g} \mathrm{N} \mathrm{m}^{-2} \mathrm{~h}^{-1}\right.$ and $37 \mu \mathrm{g} \mathrm{m}^{-2} \mathrm{~h}^{-1}$ respectively after 0 to $1 \mathrm{yr}$ and $4 \mathrm{yr}$ of glacial retreat; Schmidt et al., 2008).

The depletion, and in some cases quantitative removal of $\mathrm{NO}_{3}^{-}$(relative to icemelt) from overlying water, in some cryoconite holes on Leverett Glacier is consistent with evidence of nitrogen fixation from the acetylene assays (Fig. 5a, d), and suggests that nitrogen derived from icemelt alone can be insufficient to support the nitrogen requirements of microbial growth and activity on the glacier. Paradoxically, the estimated annual input of nitrogen from icemelt alone in the glacier zone significantly exceeds that required by $\mathrm{N}_{\mathrm{NEP}}$ (Fig. 7e). This discrepancy may be explained by one of three mutually compatible hypotheses. First, cryoconite holes may be partly hydrologically closed to total surface icemelt. Second, there may be additional microbial nitrogen assimilation in other surface ice environments, e.g. dispersed cryoconite grains (Hodson et al., 2007) or ice algae (Uetake et al., 2010). For example, dispersed cryoconite can contribute up to half the total cryoconite coverage on Arctic valley glaciers, and may have the potential to be biologically active (Hodson et al., 2007). Third, there may be significant additional loss of $\operatorname{TIN}_{(\mathrm{aq})}$ via microbial denitrification, perhaps by microbes located within the anoxic interior of cryoconite granules (Hodson et al., 2010a).

Overall, the mean importance of nitrogen fixation to microbial growth appears to decrease away from the ice sheet margins (Fig. 7c): an estimated $6.4 \pm 1.7 \%$ of $\mathrm{N}_{\mathrm{NEP}}$ in the marginal zone, $2.4 \pm 7.1 \%$ in the glacier zone, and negligible in the ice sheet zone (Fig. 7c). Some caution should be used when interpreting the absolute values of these percentages due to various uncertainties in the calculations. First, the molar ratio of ethylene produced to dinitrogen fixed may vary from the theoretical ratio of 3:1 assumed in the present study. For example, in freshwater lakes the ratio of acetylene reduced to dinitrogen fixed can vary between 2.1:1 to 11.9:1 (Howarth et al., 1988). Ideally, future studies should cross-calibrate the acetylene reduction method with the ${ }^{15} \mathrm{~N}$ tracer method (Seitzinger and Garber, 1987). Second, it is possible that the rates of acetylene reduction were not linear over the $24 \mathrm{~h}$ of incubation, although previous acetylene assay incubations using similar Arctic glacier cryoconite have been shown to be linear over this timescale (Telling 

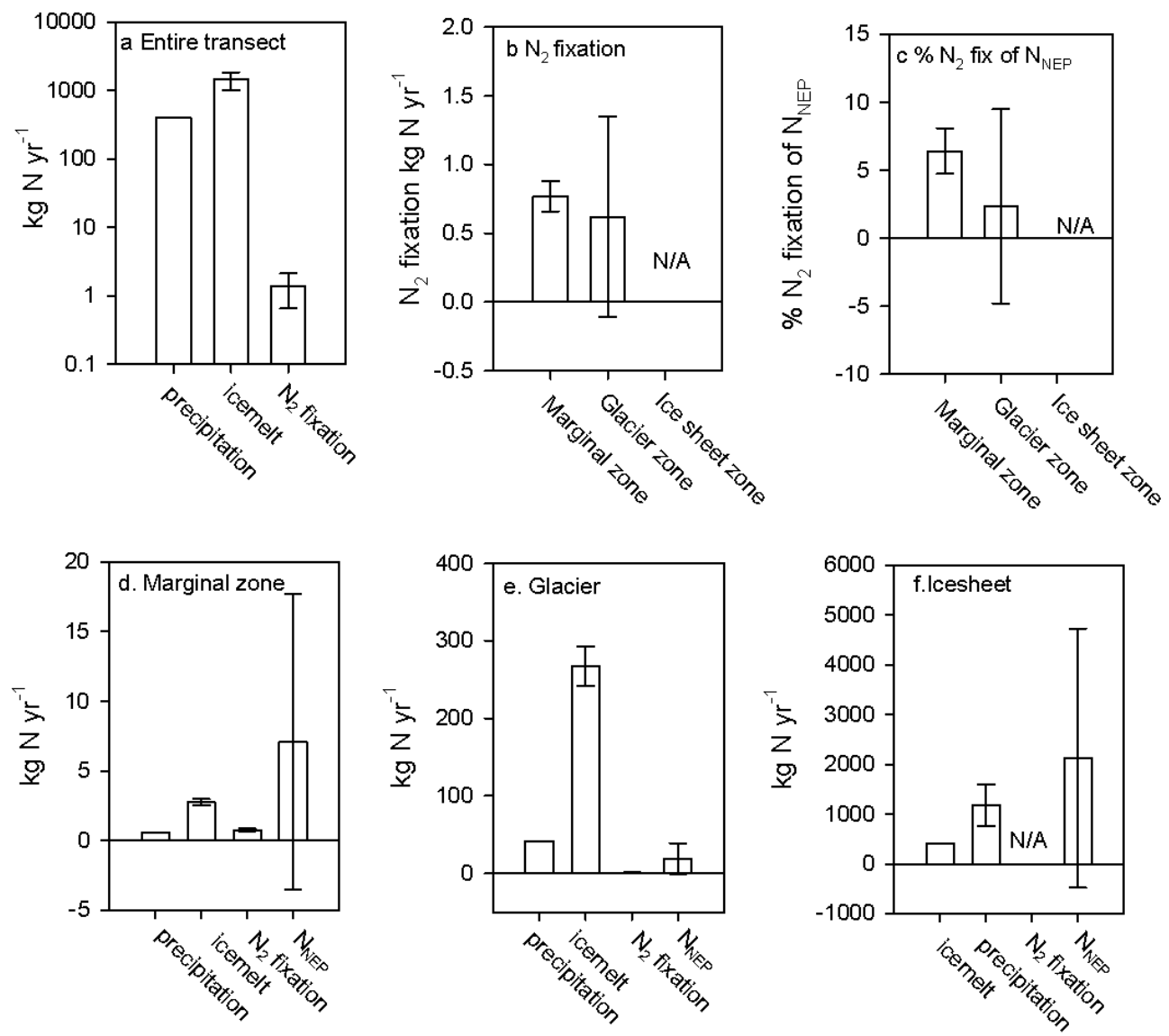

Fig. 7. Estimated annual fluxes of nitrogen over the transect. (a) Estimated annual inputs of nitrogen over the entire $79 \mathrm{~km}^{2}$ transect. (b) Estimated annual inputs of nitrogen from nitrogen fixation onto the glacier zone, marginal zone and ice sheet zone (c). Percentages of nitrogen fixation of the nitrogen demand of net ecological production $\left(\mathrm{N}_{\mathrm{NEP}}\right)$ for the glacier, marginal and ice sheet zones (d). Estimated annual fluxes of nitrogen onto the marginal zone (e). Estimated annual fluxes of nitrogen onto the glacier zone (f). Estimated annual fluxes of nitrogen onto the ice sheet zone. See main text, Sect. 2.6, for details of calculations. Error bars are $\pm 1 \sigma$.

et al., 2011). Third, the calculations of $\mathrm{N}_{\mathrm{NEP}}$ assume a balanced Redfield stoichiometry for microorganisms within cryoconite, when in reality the ratio of $\mathrm{C}: \mathrm{N}$ can vary depending on microbial species and environmental conditions (Reiners, 1986; Stal, 2000).

\subsection{Sources of inorganic nitrogen: implications for nitrogen fixation on the GrIS}

The negative relationship of potential nitrogen fixation with $\mathrm{TIN}_{(\mathrm{aq})}$ and $\mathrm{NH}_{4}^{+}$(s) (Fig. 6) indicates that the availability of inorganic nitrogen is a significant control on the presence or absence of nitrogen fixation on the GrIS. A similar negative inverse relationship between nitrogen fixation and inorganic nitrogen has previously been documented on Svalbard valley glaciers (Telling et al., 2011). Identifying the sources of inorganic nitrogen may therefore aid determining when and where nitrogen fixation occurs across the transect.

$\mathrm{NO}_{3}^{-}$(aq) concentrations in cryoconite water across the transect can most simply be explained by a combination of $\mathrm{NO}_{3}^{-}$(aq) addition via icemelt and, in the glacier zone, $\mathrm{NO}_{3}^{-}$(aq) removal by microorganisms (Fig. 5a). The source of the cryoconite-bound $\mathrm{NH}_{4}^{+}$(s) is however less certain. Nitrogen fixation can likely be ruled out, given the observed lack of $\mathrm{NH}_{4}^{+}(\mathrm{aq})$ in cryoconite holes with active nitrogen fixation (Fig. 6b). Production of $\mathrm{NH}_{4}^{+}$via dissimilatory nitrate reduction also seems unlikely given (a) the likely oxic nature of the surface waters, and (b) DIN in some cryoconite hole waters exceeded icemelt $\mathrm{TN}_{(\mathrm{aq})}$, indicating an additional source of nitrogen rather than a molar conversion of $\mathrm{NO}_{3}^{-}$(aq) to $\mathrm{NH}_{4}^{+}$(aq) (Fig. 5a). Two remaining likely sources for the observed concentrations of $\mathrm{NH}_{4}^{+}$(s) along the transect are adsorption of $\mathrm{NH}_{4}^{+}$(aq) from early season snowmelt, and/or organic matter remineralization.

Studies on Svalbard valley glaciers have demonstrated that the uptake of $\mathrm{NH}_{4}^{+}$(aq) onto cryoconite is focused within the early melt season, consistent with uptake from snowmelt (Wynn et al., 2007; Hodson et al., 2010c; Telling et al., 2011). Adsorption of early season snowmelt $\mathrm{NH}_{4}^{+}$onto cryoconite 
would allow the $\mathrm{NH}_{4}^{+}$(aq) to be utilised by microbes in the bare ice zone later into the melt season after the snow pack has migrated upslope, delaying microbial nitrogen limitation and subsequent nitrogen fixation to later in the melt season (Telling et al., 2011). In this hypothesis, nitrogen fixation becomes active in the marginal zone first, and the zone of nitrogen fixation progressively migrates upslope as the slush line retreats and available nitrogen reserves are depleted (Telling et al., 2011). The presence of nifH genes at all sites across the transect does suggest the potential for nitrogen fixation at all sites along the transect (Fig. 5e). The adsorption of snowmelt-derived $\mathrm{NH}_{4}^{+}$(aq) onto organic matter within cryoconite offers one plausible explanation for the significant $(p<0.01)$ positive correlation between TOC and $\mathrm{NH}_{4}^{+}$(s) (Fig. 5c).

The positive correlation between TOC and $\mathrm{NH}_{4}^{+}(\mathrm{s})$ (Fig. 5c) would also be equally consistent, however, with the ammonification of cryoconite organic matter. Sedimentbound $\mathrm{NH}_{4}^{+}$(s) is typically produced via organic mineralization in freshwater benthic environments (Van Raalte et al., 1974; Howarth et al., 1988; Seitzinger et al., 1991; Barett et al., 2002). Mineralization of organic matter derived either from allochthonous organic matter deposition or from accumulated past autochthonous production within cryoconite is likely to be an important additional source of recycled nitrogen to microbial communities within cryoconite holes (Stibal et al., 2012). Organic matter in cryoconite along the transect ranged from $<1 \mathrm{mg} \mathrm{Cg}^{-1}$ at the $0 \mathrm{~km}$ marginal site, $2.7 \mathrm{mg} \mathrm{Cg}^{-1}$ at the $2 \mathrm{~km}$ site, and up to $64.6 \mathrm{mg} \mathrm{Cg}^{-1}$ at the $51 \mathrm{~km}$ site (Stibal et al., 2012). Active organic matter remineralization in the glacier zone may be indicated by the presence of $\mathrm{NH}_{4}^{+}(\mathrm{aq})$ at the $4 \mathrm{~km}$ and $7.5 \mathrm{~km}$ sites (Fig. 5a). Furthermore, changes in TOC/TN ratios along the transect are consistent with organic matter remineralization. Although TOC/TN ratios in cryoconite along the transect (8.2 to 13.5 ; Fig. 5 b) are not dissimilar to those typical for microbial biomass in soils (global average of 8.6; Cleveland and Liptzin, 2007), the increase of TOC/TN from the $2 \mathrm{~km}$ to $17 \mathrm{~km}$ sites (Fig. 5b) may reflect the preferential loss of organic nitrogen over organic carbon during organic remineralization, as has previously been documented in subglacial environments (Boyd et al., 2011). The progressive loss of organic nitrogen over organic carbon from the $2 \mathrm{~km}$ to $17 \mathrm{~km}$ sites may reflect differences in the time available for organic remineralization in the glacier and ice sheet zones. Cryoconite in the glacier zone is likely to have a lower residence time, and hence less time for organic remineralization, than within the ice sheet zone (Stibal et al., 2012). This is due to steeper gradients and hence faster rates of debris flushing by supraglacial water flow in the glacier zone relative to the ice sheet zone (Stibal et al., 2012).

Both organic remineralization and snowmelt are therefore both likely significant sources of nitrogen for microbial communities on the GrIS, with further research required to deter- mine the quantitative importance of each at marginal, glacier and ice sheet zones.

\subsection{Importance of nitrogen fixation to total nitrogen inputs onto the Greenland Ice Sheet}

Results from the nitrogen mass balance estimates suggest that the importance of nitrogen fixation as a fraction of total nitrogen inputs decreases rapidly away from the ice sheet margins: an estimated $22.8 \%$ of total nitrogen inputs in the marginal zone, $0.2 \%$ in the glacier zone, to negligible in the ice sheet zone (Fig. 7). Various uncertainties in these estimates of nitrogen fixation were discussed in Sect. 4.1. Furthermore, we are basing our annual estimates of nitrogen fixation from this study alone, primarily on a single temporal snapshot of microbial activity in the peak melt season. Ideally, more measurements should be taken at regular intervals at all transect sites over the entire melt season; however, this was constrained in this study by the high cost of helicopter time. While there are no previous studies of nitrogen fixation in the marginal or ice sheet zones of ice sheets, these estimates are consistent with previous studies on glaciers. Using similar calculations, nitrogen fixation on Svalbard valley glaciers was estimated to be two orders of magnitude lower than the combined inputs from precipitation and icemelt (Telling et al., 2011). Only low numbers of culturable nitrogen fixing bacteria were documented on a New Zealand glacier, suggesting that nitrogen fixation was not a substantial source of nitrogen to glacial sediments (Foght et al., 2004). Finally, a lack of positive nitrogen fixation assays in a snow algae community (despite the detection of nifH genes) combined with low levels of $\mathrm{NH}_{4}^{+}$(aq) in supraglacial runoff has been used to suggest that nitrogen fixation is unlikely to be a significant source of nitrogen to the supraglacial environment at Robertson Glacier, Canada (Boyd et al., 2011).

We have not quantified two other potentially important nitrogen inputs in this study: dry deposition, and allochthonous deposition of organic nitrogen. Nitrogen input from dry deposition along the transect, although potentially significant, is likely to be lower than that from wet precipitation. The proportion of wet:dry deposition on the GrIS has been modelled as a function of snow accumulation rate, with dry deposition exceeding wet deposition at snow accumulation rates $>34 \mathrm{~cm} \mathrm{yr}^{-1}$, equivalent to $340 \mathrm{~kg} \mathrm{~m}^{-2}$ (Fischer et al., 1998). While dry nitrogen deposition likely dominates over the majority of the GrIS (Fischer et al., 1998), wet nitrogen deposition is likely to dominate over the length of the transect since annual wet deposition along the transect is $\sim 400 \mathrm{~kg} \mathrm{~m}^{-2} \mathrm{yr}^{-1}$ (Ettema et al., 2009).

Organic nitrogen (and organic carbon) input from allochthonous (i.e. aeolian) deposition along the transect is currently unknown. Both particulate nitrogen (likely dominantly organic nitrogen) and dissolved organic nitrogen are likely important inputs of nitrogen onto Svalbard valley glaciers (Hodson et al., 2005), and hence also likely to be significant 
sources of nitrogen on Greenland valley glaciers. Dissolved organic nitrogen cannot be ruled out as a significant source of nitrogen on the GrIS; despite being effectively undetectable in snow and ice samples with the analytical methods used in the present study (Fig. 4), it could still potentially greatly exceed nitrogen fixation as a source of nitrogen to the GrIS given the large fluxes of precipitation and icemelt onto the GrIS (Fig. 7a).

The impact of anthropogenic nitrogen deposition on the total nitrogen budget of the GrIS western ablation zone is likely to be significant given that precipitation is a major input of nitrogen to the transect (Fig. 7a) and that $\mathrm{NO}_{3}^{-}$deposition on the GrIS has doubled since preindustrial times, most likely due to fossil fuel burning (Olivier et al., 2006). The impact of anthropogenic nitrogen deposition on the total nitrogen budget of the western GrIS ablation zone is however likely to be lower than that on some high Arctic glaciers, such as those in Svalbard. In contrast to the transect of this study, annual nitrogen inputs on high Arctic Svalbard valley glaciers are likely dominated by precipitation rather than icemelt (Hodson et al., 2005). Deposition of $\mathrm{NO}_{3}^{-}$on Svalbard glaciers has increased $65 \%$ since preindustrial times due to anthropogenic deposition (largely from fossil fuel burning; Kekonen et al., 2005), substantially increasing the total nitrogen deposition on the glaciers (Hodson et al., 2005, 2010c). While $\mathrm{NO}_{3}^{-}$deposition from precipitation on the GrIS has increased even more over the same period (Olivier et al., 2006), the impact as a percentage of total nitrogen inputs is likely to be ameliorated in part by the dominance of icemelt as a nitrogen input (Fig. 7a).

Acknowledgements. This work was funded by grants awarded to A. A., A. H. and P. N. from NERC (NE/G00496X/1, NE/G006253/1, NE/F021399/1) and to MS from Marie Curie Reintegration Grant No. 249171 (ProGrIS). We would like to thank Arwyn Edwards, Eric Boyd and two anonymous reviewers for their constructive comments which have greatly strengthened this paper.

Edited by: J. Middelburg

\section{References}

Anesio, A. M., Hodson, A. J., Fritz, A., Psenner, R., and Sattler, B.: High microbial activity on glaciers: importance to the global carbon cycle, Global Change Biol., 15, 955-960, doi:10.1111/j.1365-2486.2008.01758.x, 2009.

Baron, J. S., Allstott, E. J., and Newkirk, B. K.: Analysis of long term sulfate and nitrate budgets in a Rocky Mountain basin, IAHS-AISH P., 228, 255-261, 1995.

Barrett, J. E., Virginia, R. A., and Wall, D. H.: Trends in resin and $\mathrm{KCl}$-extractable soil nitrogen across landscape gradients in Taylor Valley, Antarctica, Ecosystems, 5, 289-299, 2002.

Boyd, E. S., Lange, R. K., Mitchell, A. C., Havig, J. R., Hamilton, T. L., Lafreniere, M. J., Shock, E. L., Peters, J. W., and Skidmore, M.: Diversity, abundance and potential activity of nitrify- ing and nitrate-reducing microbial assemblages in a subglacial ecosysetm, Appl. Environ. Microbiol., 77, 4778-4787, 2011.

Breitbarth, E., Mills, M. M., Friedrichs, G., and LaRoche, J.: The Bunsen gas solubility coefficient of ethylene as a function of temperature and salinity and its importance for nitrogen fixation assays, Limnol. Oceanogr. Methods, 2, 282-288, 2004.

Campbell, D. H., Baron, J. S., Tonnessen, K. A., Brooks, P. D., and Schuster, P. F.: Controls on nitrogen flux in alpine/subalpine watersheds of Colorado, Water Resour. Res., 36, 37-47, 2000.

Church, M. J., Short, C. M., Jenkins, B. D., Karl, D. M., and Zehr, J. P.: Temporal patterns of nitrogenase gene (nifH) expression in the oligotrophic North Pacific Ocean, Appl. Environ. Microbiol., 71, 5362-5370, 2005.

Cleveland, C. C. and Liptzin, D.: C:N:P stoichiometry in soil: is there a "Redfield ratio" for the microbial biomass?, Biogeochemistry, 85, 235-252, 2007.

Ettema, J., van den Broeke, M. R., van Meijgaard, E., van de Berg, W. J., Bamber, J. L., Box, J. E., and Bales, R. C.: Higher surface mass balance of the Greenland ice sheet revealed by highresolution climate modelling, Geophys. Res. Lett., 36, L12501, doi:10.1029/2009GL038110, 2009.

Fischer, H., Wagenbach, D., and Kipfstuhl, J.: Sulfate and nitrate firn concentrations on the Greenland ice sheet 1. Large-scale geographical deposition changes, J. Geophs. Res., 102, 2192721934, 1998.

Foght, J., Aislabie, J., Turner, S., Brown, C. E., Ryburn, J., Saul, D. J., and Lawson, W.: Culturable bacteria in subglacial sediments and ice from two southern hemisphere glaciers, Microb. Ecol. 47, 329-340, 2004.

Hodson, A.: Biogeochemistry of snowmelt in an Antarctic glacial ecosystem, Water Resources Res., 42, W11406, doi:10.1029/2005WR004311, 2006.

Hodson, A. J., Mumford, P. N., Kohler, J., and Wynn, P. M.: The High Arctic glacial ecosystem: New insights from nutrient budgets, Biogeochemistry, 72, 233-256, 2005.

Hodson, A., Anesio, A. M., Ng, F., Watson, R., Quirk, J., IrvineFynn, T., Dye, A., Clark, C., McCloy, P., Kohler, J., and Sattler, B.: A glacier respires: Quantifying the distribution and respiration $\mathrm{CO}_{2}$ flux of cryoconite across an entire Arctic supraglacial ecosystem, J. Geophys. Res., 112, G04S36, doi:10.1029/2007JG000452, 2007.

Hodson, A., Anesio, A. M., Tranter, M., Fountain, A., Osborn, M., Priscu, J., Laybourn-Parry, J., and Sattler, B.: Glacial ecosystems, Ecol. Monogr., 78, 41-67, doi:10.1890/07-0187.1, 2008.

Hodson, A., Heaton, T., Langford, H., and Newsham, K.: Chemical weathering and solute export by meltwater in a maritime Antarctic glacier basin, Biogeochemistry, 98, 9-27, 2009.

Hodson, A., Cameron, K., Bøggild, C., Irvine-Fynn, T., Langford, H., Pearce, D., and Banwart, S.: The structure, biological activity and biogeochemistry of cryoconite aggregates upon an Arctic valley glacier: Longyearbyen, Svalbard, J. Glaciol, 196, 349362, 2010a.

Hodson, A., Bøggild, C., Hanna, E., Huybrechts, P., Langford, H., Cameron, K., and Houldsworth, A.: The cryoconite ecosystem upon the Greenland Ice Sheet, Ann. Glaciol. 51, 123-129, 2010b.

Hodson, A., Roberts, T. J., Engvall, A.-C., Holmen, K., and Mumford, P.: Glacier ecosystem response to episodic nitrogen enrichment in Svalbard, European High Arctic, Biogeochemistry, 98, 171-184, doi:10.1007/s10533-009-9384-y, 2010c. 
Howarth, R. W., Marino, R., Lane, J., and Cole, J. C.: Nitrogen Fixation in Freshwater, Estuarine, and Marine Ecosystems. 1. Rates and Importance, Limnol. Oceanogr., 33, 669-687, 1988.

Kekonen, T., Moore, J., Perämäki, P., Mulvaney, R., Isaksson, E., Pohjola, V., and van de Wal, R. S. W.: The 800 year long ion record from the Lomonosovfonna (Svalbard) ice core, J. Geophys. Res., 110, D07304, doi:10.1029/2004JD005223, 2005.

Olivier, S., Blaser, C., Brütsch, S., Frolova, N., Gäggeler, H. W., Henderson, K. A., Palmer, A. S., Papina, T., and Schwikowski, M.: Temporal variations of mineral dust, biogenic tracers, and anthropogenic species during the past two centuries from Belukha ice core, Siberian Altai, J. Geophys. Res., 111, D05309, doi:10.1029/2005JD005830, 2006.

Redfield, A. C., Ketchum, B. H., and Richards, F. A.: The influence of organisms on the composition of seawater, The sea, Vol. 2, edited by: Hill, M. H., 26-77, Wiley, New York, 1963.

Reiners, W. A.: Complementary models for ecosystems, Am. Nat., 127, 59-73, 1986.

Schmidt, S. K., Reed, S. C., Nemergut, D. R., Grandy, A. S., Cleveland, C. C., Weintraub, M. N., Hill, A. W., Costello, E. K., Meyer, A. F., Neff, J. C., and Martin, A. M.: The earliest stages of ecosystem succession in high-elevation (5000 metres above sea level), recently deglaciated soils, Proc. Roy. Soc. B-Biol. Sci., 275, 2793-2802, 2008.

Seitzinger, S. P. and Garber, J. H.: Nitrogen fixation and 15N2 calibration of the acetylene assay in coastal marine sediments, Mar. Ecol. Prog. Ser., 37, 65-73, 1987.

Seitzinger, S. P., Gardner, W. S., and Spratt, A. K.: The effect of salinity on ammonium sorption in aquatic sediments - implications for benthic nutrient recycling, Estuaries, 14, 167-174, 1991.

Stal, L. J.: Cyanobacterial mats and stromatolites, The Ecology of Cyanobacteria, edited by: Whitton, B. A. and Potts, M., 61-120, Kluwer Academic Publisher, Dordrecht, 2000.

Stewart, W. D., Fitgeral, G. P., and Burris, R. H.: In situ studies on $\mathrm{N}_{2}$ fixation using the acetylene reduction technique, Proc. Natl. Acad. Sci. USA, 58, 2071-2078, 1967.
Stibal, M., Lawson, E. C., Lis, G. P., Mak, K. M., Wadham, J. L., and Anesio, A. M.: Organic matter content and quality in supraglacial debris across the ablation zone of the Greenland ice sheet, Ann. Glaciol., 51, 1-8, 2010.

Stibal, M., Telling, J., Cook, J., Mak, K. M., Hodson, A., and Anesio, A. M.: Environmental controls on microbial abundance and activity on the Greenland ice sheet: a multivariate analysis approach, Microbial Ecol., 63, 74-84, 2012.

Telling, J., Anesio, A. M., Hawkings, J., Tranter, M., Wadham, J. L., Hodson, A. J., Irvine-Fynn, T., and Yallop, M. L.: Measuring rates of gross photosynthesis and net community production in cryoconite holes: a comparison of field methods, Ann. Glaciol., 51, 153-162, 2010.

Telling, J., Anesio, A. M., Tranter, M., Irvine-Fynn, T., Hodson, A., Butler, C., and Wadham, J. L.: Nitrogen fixation on Arctic glaciers, Svalbard, J. Geophys. Res., 116, G03039, doi:10.1029/2010JG001632, 2011.

Tockner, K., Malard, F., Uehlinger, U., and Ward, J. V.: Nutrients and organic matter in a glacial river-floodplain system (Val Roseg, Switzerland), Limnol. Oceanogr., 47, 266-277, 2002.

Uetake, J., Naganuma, T., Hebsgaard, M. B., Kanda, H., and Kohshima, S.: Communities of algae and cyanobacteria on glaciers in west Greenland, Polar Sci., 4, 71-80, 2010.

Van Raalte, C. D., Valiela, I., Carpenter, E. J., and Teal, J. M.: Inhibition of nitrogen fixation in salt marshes measured by acetylene reduction, Estuarine Coastal Mar. Sci., 2, 201-305, 1974.

Walker, D. A., Raynolds, M. K., Daniels, F. J. A., Einarsson, E., Elvebakk, A., Gould, W. A., Katenin, A. E., Kholod, S. S., Markon, C. J., Melnikov, E. S., Moskalenko, N. G., Talbot, S. S., Yurtsev, B. A., and other members of the CAVM Team: The Circumpolar Arctic vegetation map, J. Vegetation Sci., 16, 267282, 2005.

Wang, L., Sharp, M., Rivard, B., and Steffen, K.: Melt season duration and ice layer formation on the Greenland ice sheet, 2000-2004, J. Geophys. Res.-Earth Surface, 112, F04013, doi:10.1029/2007JF000760, 2007.

Wynn, P. M., Hodson, A. J., Heaton, T. H. E., and Chenery, S. R.: Nitrate production beneath a High Arctic glacier, Svalbard, Chem. Geol., 244, 88-102, 2007. 